\title{
Habitat selection of the pink shrimp Farfantepenaeus paulensis and the blue crab Callinectes sapidus in an estuary in southern Brazil: influence of salinity and submerged seagrass meadows
}

Vinicius Mendes Ruas, Marcos Alaniz Rodrigues, Luiz Felipe Cestari Dumont and Fernando D'Incao

(VMR, MAR, LFCD, FD) Federal University of Rio Grande (FURG) - Laboratory of Decapod Crustaceans. Rio Grande, RS, Brazil. CEP: 96201-900 - P.O. Box: 474. E-mail: (VMR) ambiental.vm@gmail.com

\begin{abstract}
This study was conducted in two estuarine inlets (Saco da Mangueira and Saco do Arraial) at the Patos Lagoon estuary, southern Brazil. The changes in relative abundance and size of post-larvae and juvenile shrimp Farfantepenaeus paulensis and juvenile blue crab Callinectes sapidus were compared, considering the influence of salinity and the presence of submerged seagrass meadows. The analyses were performed using generalized linear models (GLM) for abundance variations and ANOVA for variations on the size of individuals. The pink shrimp was more abundant at Saco da Mangueira, in seagrass meadows and areas of higher salinity. The blue crab was more abundant at Saco do Arraial and in lower levels of salinity. The importance of submerged vegetation for the blue crab lies in a preference of smaller crabs of the species for the seagrass meadows. It has been shown that these species choose different habitats in the estuary, and both the salinity and the presence of submerged seagrass meadows influence the selection of habitat.
\end{abstract}

Key words: Crustaceans, GLM, Patos Lagoon, submerged vegetation

\section{INTRODUCTION}

The pink shrimp Farfantepenaeus paulensis (Pérez Farfante, 1967) and the blue crab Callinectes sapidus Rathbun, 1896 are estuarine during part of their life cycle, i.e., post-larvae and juvenile pink shrimp and the stages of zoea, megalopa, juvenile and adult of the blue crab (Hines et al., 1987; Bulger et al., 1995; D'Incao, 1991; Costa et al., 2008; Rodrigues and D'Incao, 2008; Vieira and Calazans, 2010; Rodrigues and D'Incao, 2014). The entry of these organisms into estuaries follows the patterns observed in other species of penaeids and also blue crabs from other coastal regions (D'Incao, 1991; Lhomme, 1992; Bulger et al., 1995; Epifanio, 2007; Cházaro-Olvera et al., 2009). These species are considered important links in the food web that exert strong predation pressure on benthic invertebrates (Kapusta and Bemvenuti, 1998; Oliveira et al., 2006; Jorgensen et al., 2009). Besides providing great ecological value, they also represent a significant source of income for fishermen due to their high commercial value (D'Incao et al., 2002; Kalikoski and Vasconcellos, 2013).

The salinity decrease in estuaries is a limiting factor for distribution and abundance of Melicertus plebejus (Hess, 1865) and Fenneropenaeus merguiensis (De Man, 1888) post-larvae (Young and Carpenter, 1977; Vance et al., 1998). However, the distribution of $F$ paulensis post-larvae to the innermost regions of estuaries has not been studied, and the influence of salinity is often associated with 
the abundance of juveniles and to fisheries production (D'Incao, 1991; Costa et al., 2008; Möller et al., 2009; Pereira and D'Incao, 2012). The distribution of pink shrimp in the Patos Lagoon estuary (Rio Grande do Sul state, Brazil) was investigated by D'Incao (1991), though a real quantification of possible spatial variations on the abundance of the species was not carried out. The author indicates the greatest abundance of the pink shrimp is found in the estuarine inlets, where supply of food is higher, and which provides refuge from predators. The spatial variations in relative abundance associated with fishery activities may indicate variations in the abundance of juveniles among the estuarine inlets (Ruas et al., 2011).

As for the blue crab, important factors for habitat selection in estuaries of the coasts of Virginia and North Carolina and the Gulf of Mexico in the United States are intraspecific competition, search for food, protection from predators and salinity (Orth and van Montfrans, 1987; Williams et al., 1990; Hovel and Lipcius, 2002; Lipcius, 2005; Posey et al., 2005). Studies show that during the juvenile development the greatest abundance of the blue crab were found in lower salinities and that the use of different habitats is related to the size of the individuals (Orth and van Montfrans, 1987; Williams et al., 1990; Posey et al., 2005). Segregation by sex is a characteristic of this species and it is related to the reproductive behavior of female migration towards the entrance of the estuary after copulation to reach the ocean and spawn (Epifanio, 2007; Rodrigues and D'Incao, 2014). Male individuals reach low salinity areas of the upper estuary (Epifanio, 2007; Rodrigues and D'Incao, 2014), though a possible habitat selection during the juvenile growth in the estuary still needs investigation.

In this context, it has been shown that the greatest abundance of post-larvae and juveniles of penaeid and blue crab are associated with the presence of submerged seagrass (Orth and van Montfrans, 1987; Williams et al., 1990; Haywood et al., 1995; Garcia et al., 1996;
Sánchez, 1997; Pérez-Castañeda and Defeo, 2001; 2004; Hovel and Lipcius, 2002; Heck Jr et al., 2003; Lipcius, 2005; Pérez-Castañeda et al., 2010). The structural complexity of phanerogams promotes the stabilization of the environment by attenuating currents and waves and of the sediment through increased deposition of organic and inorganic particles, as well as offering protection and a larger volume of high quality food (Perkins-Visser et al., 1996; Lee et al., 2007).

Seagrass can also be characterized as an important nursery environment (Heck Jr et al., 2003). In a shallow inlet of the Patos Lagoon estuary, Garcia et al. (1996) observed the greatest abundance of juvenile pink shrimp and juvenile blue crab in the prairies of Ruppia maritima (Linnaeus, 1753), the dominant species in substrates with phanerogam vegetation (Copertino and Seeliger, 2010). The authors concluded that these habitats offer better feeding conditions for these crustaceans. It is noteworthy that Garcia et al. (1996) did not capture post-larvae, nor compared the size of the individuals, which could indicate segregation by size showing the preference of the smallest crustaceans for a vegetated bottom that could offer protection (Williams et al., 1990; Pérez-Castañeda and Defeo, 2001).

Therefore, this study investigated the habitat selection of post-larvae and juveniles of $F$. paulensis and juveniles of $C$. sapidus between two estuarine inlets in the Patos Lagoon by comparing possible variations in relative abundance and size. The effect of salinity and the presence of submerged seagrass meadows were analyzed.

\section{Material And Methods}

Area of study

The study was conducted in two shallow inlets from the low and middle Patos Lagoon estuary, called Saco da Mangueira (SM) and Saco do Arraial (SA) (Fig. 1). These areas have reduced circulation, sandy sediment and are among the main areas with submerged seagrass meadows (Copertino and Seeliger, 2010). 


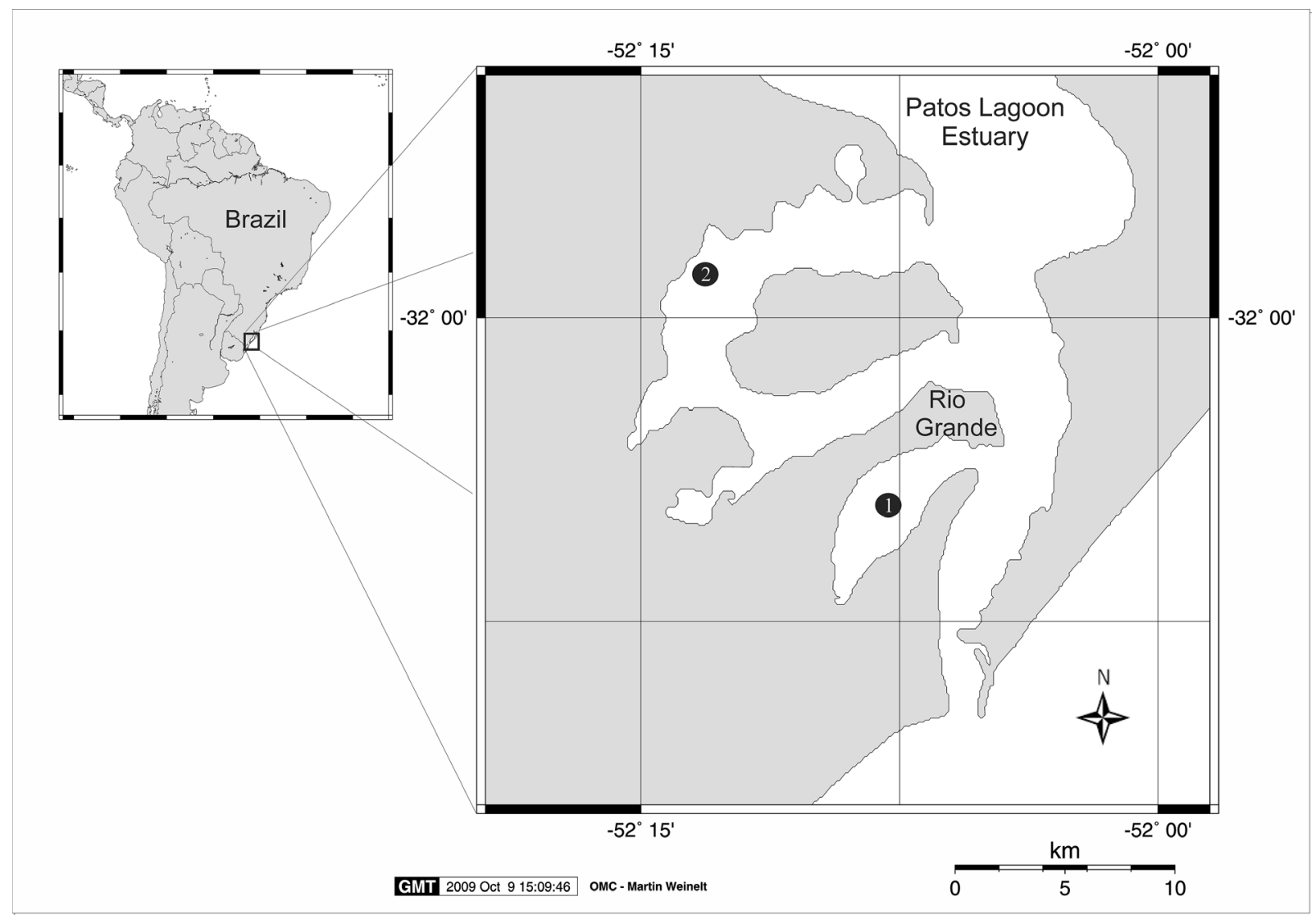

Figure 1. Patos Lagoon estuary, RS, Brazil. Numbers represent the "Saco da Mangueira" (SM) inlet (1), and Saco do Arraial (SA) inlet (2). Source: http://www.aquarius.ifm-geomar.de/

\section{Data sampling and biometrics}

The samples were collected during daytime every two weeks when prairies were available (from October 2010 to February 2011), in the prairie (vegetated - VE) and in another area adjacent to the prairie area, but unvegetated (UVE). The samples were collected on the same day in the two inlets at locations with depth less than 1.5 meters.

First, the samples were collected with an adapted trawl net, using a bagger with a mesh size of $500 \mu$ adapted to the rear end and a net with a $5 \mathrm{~mm}$-distance between knots (Renfro, 1963). The net opening was rigid and measured $1.8 \mathrm{~m}$. Each trawling had an extension of 40 $\mathrm{m}$. At each collection point two trawlings were conducted in the VE area, and two in the UVE area. To minimize the effect of the boat close to the trawling locations, the engine was turned off and the displacement of the boat was done with an oar. At the sampling site, the fishing net was placed in the water and the cable stretched to reach the mark of 40 meters. After that, the boat was anchored to prevent variation in the trawling distance, and the trawl net was drawn manually. In addition, the salinity level was checked during each trawling through a mini portable probe YSI 556 MPS model. The collected material was stored in properly labeled plastic bags, containing 4\% formaldehyde.

The samples were washed under running water with a sieve of $500 \mu$, separated and identified in the level of species according to Melo (1996) and D'Incao (1999). The pink shrimp post-larvae were identified according to Calazans (1993). In this study, post-larvae were considered as the shrimp with up to 3 $\mathrm{mm}$ of carapace length, and shrimps above this size were classified as juveniles (Haywood et al., 1995). The relative abundance of each species was determined by counting the organisms from each trawling.

Millimetrical measurements of the postlarvae carapace length (CL), from the orbital angle to the dorsal edge of the carapace, were obtained with a stereomicroscope equipped with an ocular micrometer and CL of juvenile 
pink shrimp were obtained using a caliper $(0.1 \mathrm{~mm})$. Millimetrical measurements of carapace width $(\mathrm{CW})$ of juvenile blue crab were obtained between the first anterolateral spines of the carapace with a caliper.

\section{Data Analysis}

The analyses were performed with the software R (version 3.0.1; R. Development Core Team, 2013). Abundance was modeled using Generalized Linear Models (GLM) with the family of negative binomial distribution that allows the incorporation of the overdispersion, which is typical of count data (McCullagh and Nelder, 1989). The presence of submerged vegetation (VE or UVE), the sampling site (SM or SA) and the salinity are the explaining variables on the abundance of organisms. These models were applied to analyze possible variations on the abundance (response variable) for the pink shrimp (post-larvae and juveniles) and for the blue crab.

The selection criteria for the best model was based on the choice of the lowest value for AIC - Akaike's Information Criteria (Burnham and Anderson, 2002). To detect models with equivalent predictive capacity, the value of $\Delta_{i}$ was used, which is the difference between the AIC of a model "i" and the lower AIC value found $\left(\Delta_{\mathrm{i}}=\mathrm{AIC}_{\mathrm{i}}-\mathrm{AIC}_{\text {low }}\right)$ (Burnham and Anderson, 2002). Models with $\Delta_{\mathrm{i}}$ between 0 and 2 are classified as indistinguishable from the best model; $\Delta_{i}$ between 4 and 7 are models with lower predictive quality, and models with $\Delta_{\mathrm{i}}$ greater than 10 can be discarded as being unimportant (Burnham and Anderson, 2002). The models with $\Delta_{i}$ between 0 and 2 were selected and named as "PL" for post-larvae, "J" for juveniles of pink shrimp, and $\mathrm{C}$ for crabs.

The size of individuals was compared using CL and CW values. The statistical predictions were tested with the DurbinWatson routines for addiction, KolmogorovSmirnov test for normality and Cochran test for homoscedasticity. The original values of CL were logarithm-transformed $(\log (\mathrm{CL}+1)$ for pink shrimp, and square root-transformed for the CW of crabs [Sqrt (CW + 3/8)] (Zar, 1984). The calculated means are presented with the confidence interval of 95\% (in parenthesis).
A factorial ANOVA type III for unbalanced data (Shaw and Mitchell-Olds, 1993; Quinn and Keough, 2002) was used to analyze variations on measurements, with the inlets (SM and SA values) and vegetation (VE and UVE values) as factors. After that, the significance of the data was tested with the Tukey test with a level of significance of 5\% (Zar, 1984).

The ANOVA was used even when the homoscedasticity was not confirmed, because the analysis is robust to violations of this prediction (Zar, 1984). However, to minimize the chances of a type I error, a level of significance of $1 \%$ was used (Underwood, 1981).

\section{RESUlTS}

\section{Model selection and estimates of explicative variables}

The number of post-larvae collected in SM was $39(\mathrm{VE}=29$; UVE $=10)$ and only five in $\mathrm{SA}(\mathrm{VE}=3$; $\mathrm{UVE}=2)$. Juvenile pink shrimp were also more abundant in SM, with a total of 479 individuals captured (VE = 317; UVE = 162), whereas 97 were captured in SA (VE $=62 ; \mathrm{UVE}=35$ ). The greater abundance of post-larvae and juveniles occurred in the VE area of SM. Blue crabs were more abundant in SA where 301 individuals were captured $(\mathrm{VE}=201$; $\mathrm{UVE}=100)$, whereas only 94 were captured in SM (VE = 42; UVE = 52). Two models to explain the variation on the relative abundance of the pink shrimp post-larvae were selected (PL1; PL2), together with one model for pink shrimp juveniles $(\mathrm{J})$ and one model for the blue crab (C) (Tab. 1). The estimates of the explanatory variables with their respective $p$-values are presented in Table 2.

The PL1 and PL2 models presented a positive coefficient for the variable "vegetVE" and also showed that the abundance of postlarvae was significantly higher (Tab. 2) in the vegetated area (Fig. 2). On the PL2 model, the positive coefficient of "inletSM" shows significant influence (Tab. 2), indicative of greater abundance of post-larvae on the SM 
Table 1. Models selected to explain the variation on the relative abundance of blue crab (C) and post-larvae (PL) and juveniles (J) of the pink shrimp. The values of Akaike's Information Criterion (AIC) and the difference between the value of a model "i" and the model with the lowest AIC value $\left(\Delta_{\text {AIC }}\right)$ are shown. Inlet = shallow inlet where samples were collected; salt = salinity; veget = presence or absence of vegetation; “*” indicates the interaction between the explaining variables.

\begin{tabular}{lcccc}
\hline \multicolumn{1}{c}{ ORGANISMS } & NUMBER & MODEL & AIC & $\Delta_{\text {AIC }}$ \\
\hline \multirow{2}{*}{ Post-larvae } & OF MODEL & inlet*salt+veget & 126.5363 & 0 \\
Pink shrimp & PL1 & veget+inlet & 127.2283 & 0.692 \\
Blue crab & J & inlet*salt+veget & 338.3921 & 0 \\
\hline
\end{tabular}

Table 2. Estimates of the explanatory variables for each model selected. Significant values $(p<0.05)$ are presented in bold. Low $\mathrm{p}$ value is indicated by “*”.

\begin{tabular}{lrrr}
\hline \multirow{2}{*}{ MODEL } & $\begin{array}{c}\text { EXPLICATIVE } \\
\text { VARIABLES }\end{array}$ & ESTIMATE & p-VALUE \\
\hline PL 1 & inletSM & 0.9440 & 0.2529 \\
& salt & -0.3469 & 0.0997 \\
& vegetVE & 1.0484 & $\mathbf{0 . 0 3 3 7}$ \\
PL 2 & inletSM*sal & 0.3352 & 0.1157 \\
& vegetVE & 0.9820 & $\mathbf{0 . 0 4 5 9}$ \\
J inletSM & 1.9460 & $\mathbf{0 . 0 0 0 6}$ \\
& inletSA & 0.9553 & 0.1963 \\
& salt & 0.1032 & $\mathbf{0 . 0 0 1 5}$ \\
& vegetVE & 0.7921 & $* 0.0635$ \\
C & inletSA*salt & -0.2314 & $\mathbf{0 . 0 0 1 4}$ \\
& inletSA & 1.0542 & $\mathbf{0 . 0 1 7 0}$ \\
& salt & -0.0039 & 0.8303 \\
& vegetVE $^{*}-0.2217$ & 0.5047 \\
& inletSA*salt & -0.0826 & $\mathbf{0 . 0 1 7 0}$ \\
& inletSA*veget & 0.8106 & $* 0.0659$ \\
\hline
\end{tabular}

inlet (Fig. 2). The higher salinity records occurred on SM (Fig. 3) with a mean of 14.58 (11.90 to 17.25$)$, whereas the average salinity was 5.93 (3.16 to 8.69) in SA.

The J model showed a significantly positive coefficient for "salt", indicating that the abundance of juvenile pink shrimp increases as salinity increases, though this effect occurs mainly in the SM inlet (see Fig. 3). This model showed an interaction between inlet and salinity to explain the variation of the abundance of the shrimps, showing a significantly negative coefficient for the variable "inletSA*salt". This interaction shows that the abundance of the juvenile shrimp does not increase with the salinity in the SA inlet. The highest abundances of the shrimp in the SA inlet occurred in salinities below 10 (Fig. 3). The low $p$ value (Tab. 2) for the effect of vegetation on the abundance of juveniles in the J model shows a propensity of a higher abundance of the pink shrimp in vegetated areas, which is more evident in SM (Fig. 2).
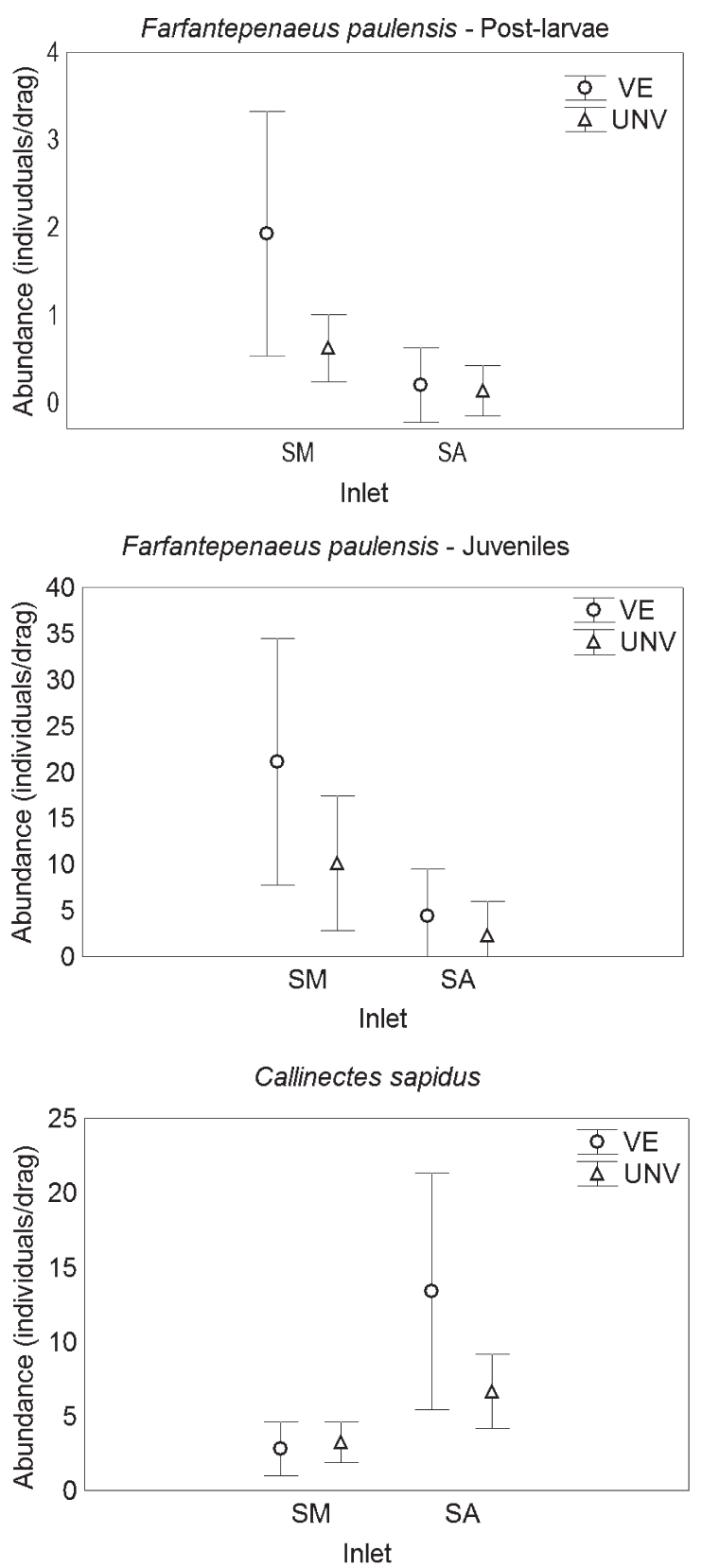

Figure 2. Variations of relative mean abundance of Farfantepenaeus paulensis and Callinectes sapidus in the shallow inlets Saco da Mangueira (SM) and Saco do Arraial (SA), expressed by the number of individuals caught by trawling, by comparing a vegetated submerged seagrass area (VE) with an adjacent unvegetated bottom (UVE). Vertical bars show the $95 \%$ confidence interval. 

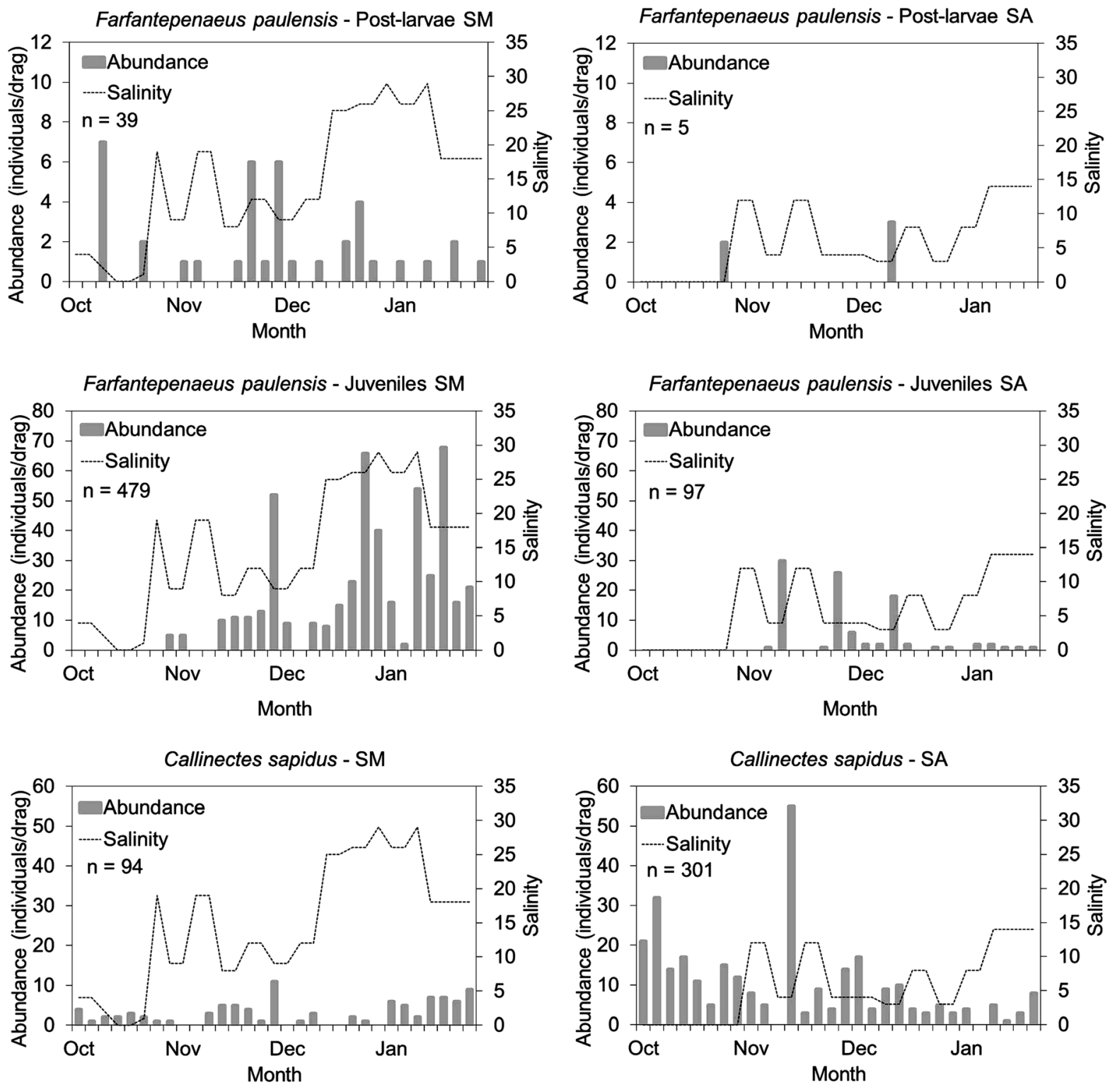

Figure 3. Changes in the relative abundance of Callinectes sapidus and Farfantepenaeus paulensis in Saco da Mangueira (SM) and Saco do Arraial (SA), expressed by the total number of individuals caught per trawling (bars) compared with the variation of salinity (lines) during the months of study (October-February).

The $\mathrm{C}$ model had a positive coefficient for "inletSA" and a negative coefficient for the interaction between "inletSA*salt". The relative abundance of crabs in the SA inlet was higher than in SM and the interaction indicated that the abundance of these organisms decreased while salinity increased (Figs. 2 and 3). The model showed no significant influence on the presence of vegetation, however, the low $p$ value (Tab. 2) for interaction "inletSA*veget" indicates that there is a tendency of crabs to be more abundant in the vegetated SA area (Fig. 2).
Size of individuals

The mean CL of shrimp harvested in SM was $7.59 \mathrm{~mm}$ (7.20 to 7.98$)$ in VE and $7.58 \mathrm{~mm}$ (7.03 to 8.14) in UVE, whereas in SA it was $7.29 \mathrm{~mm}(6.40$ to 8.19$)$ in VE and $7.37 \mathrm{~mm}$ (6.18 to 8.55) in UVE (Fig. 4). The mean CW of blue crab in SM was $51.02 \mathrm{~mm}$ (45.01 to 57.04) in VE and $58.24 \mathrm{~mm}$ (52.92 to 63.57) in UVE, and in SA it was $25.95 \mathrm{~mm}$ (23.24 to 28.66) in VE and $36.11 \mathrm{~mm}$ (32.25 to 39.97) in UVE (Fig. 5).

The residual analysis of the transformed CL values for the pink shrimp showed that 


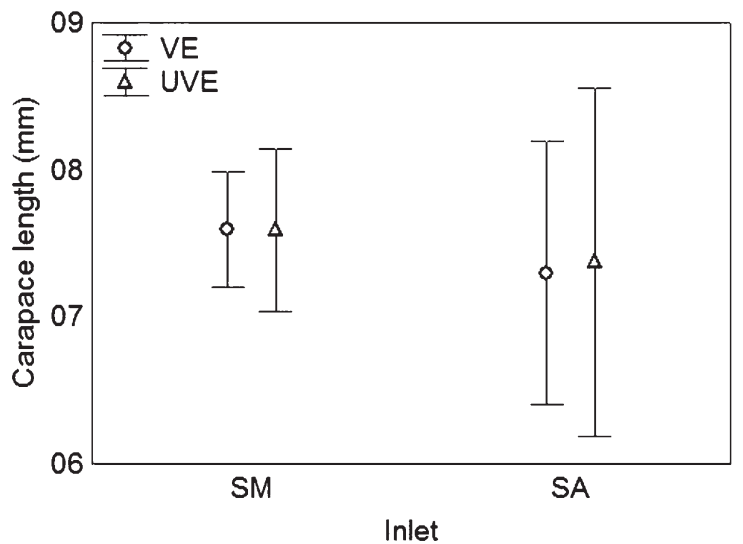

Figure 4. Changes in mean carapace length of Farfantepenaeus paulensis in Saco da Mangueira (SM) and Saco do Arraial (SA), comparing a vegetated submerged seagrass (VE) area with an unvegetated bottom adjacent (UVE). Vertical bars show the $95 \%$ confidence interval.

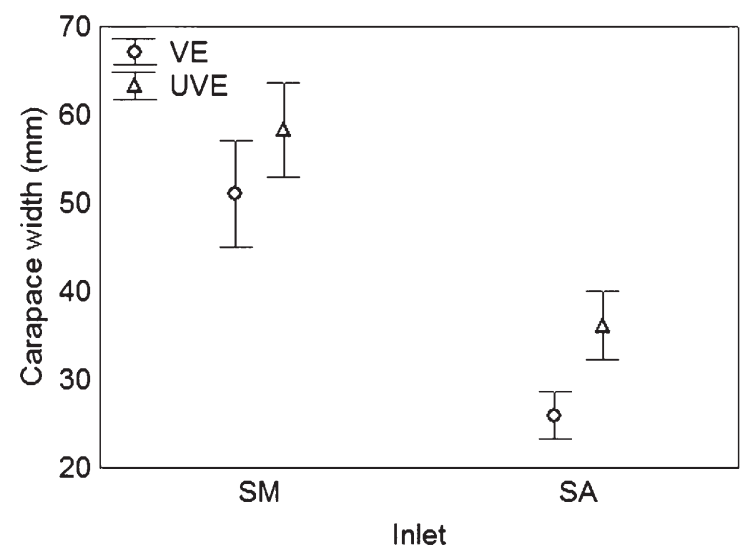

Figure 5. Changes in mean carapace length of Callinectes sapidus in Saco da Mangueira (SM) and Saco do Arraial (SA), comparing a vegetated submerged seagrass area (VE) with an adjacent unvegetated area (UVE). Vertical bars show the $95 \%$ confidence interval.

Table 3. Comparison of carapace length (CL) of Farfantepenaeus paulensis, and carapace width (CW) of Callinectes sapidus, among the inlets and vegetation, showing the interaction between these factors. ANOVA results containing SSQ (Sum of Squares), DF (degrees of freedom), AS (average square), F and p. Significant differences $(p<0.01)$ are presented in bold.

\begin{tabular}{|c|c|c|c|c|c|}
\hline \multicolumn{6}{|c|}{ ANOVA } \\
\hline EFFECT & SSQ & DF & AS & $\mathrm{F}$ & $\mathrm{p}$ \\
\hline \multicolumn{6}{|l|}{ Pink shrimp CL } \\
\hline Intercept & 1315.113 & 1 & 1315.113 & 7766.875 & 0.0000 \\
\hline Inlet & 0.065 & 1 & 0.065 & 0.383 & 0.5360 \\
\hline Vegetation & 0.013 & 1 & 0.013 & 0.077 & 0.7818 \\
\hline Inlet*vegetation & 0.001 & 1 & 0.001 & 0.009 & 0.9265 \\
\hline Error & 102.779 & 607 & 0.169 & & \\
\hline Blue crab - CW & & & 5 & & \\
\hline Intercept & 10353.10 & 1 & 10353.105 & 4215.780 & 0.0000 \\
\hline Inlet & 164.15 & 1 & 164.15 & 66.840 & 0.0000 \\
\hline Vegetation & 43.44 & 1 & 43.44 & 17.689 & 0.0000 \\
\hline Inlet*vegetation & 0.50 & 1 & 0.50 & 0.203 & 0.6525 \\
\hline Error & 935.66 & 381 & 2.46 & & \\
\hline
\end{tabular}

the data were independent $(p=0.48)$, normal $(p>0.20)$ and homoscedastic $(\mathrm{p}=0.41)$. For the blue crab, data reached independency $(p=0.77)$ and normality $(p>0.20)$, but not homoscedasticity $(p=0.00)$.

The ANOVA applied to the CL of the shrimps showed no significant differences between the size of the individuals for the main effects (inlet and vegetation) or for the interaction of factors (vegetation*inlet) (Tab. $3)$. On the other hand, ANOVA results for the blue crabs showed that there were significant differences in the inlet and vegetation effects, but no interaction (Tab. 3).

The Tukey test showed that the average carapace width of the crabs was significantly different in the UVE of the SM when compared to $\mathrm{VE}$ and UVE of SA. In the vegetated area of SM, the average CW was only significantly different when compared with the average $\mathrm{CW}$ vegetated area of SA. There were significant differences between the VE and UVE areas of SA.

The highest mean values of blue crabs $\mathrm{CW}$ occurred in SM, and the highest mean length values recorded in this inlet were in UVE. Nevertheless, when comparing the VE and UVE areas of this inlet, there were no 
relevant differences in the size of individuals. The blue crabs showed significantly higher mean CW values in the VE area of SM than in the VE area of SA. In the SA inlet, where the lowest values were found, the mean carapace width of crabs was significantly lower in VE (Fig. 5).

\section{Discussion}

Post-larvae and pink shrimp juveniles: inlets and salinity influence

Although in this work the models have not demonstrated salinity as an important variable to explain the variation on the abundance of post-larvae, the records of higher salinity in SM with significantly greater abundance of post-larvae indicate there was a more favorable scenario for the arrival and settlement of these organisms in this inlet. The entries of the pink shrimp Farfantepenaeus paulensis post-larvae in the Patos Lagoon estuary are regulated by the intensity and direction of the wind and the freshwater discharge from the lagoon system (D'Incao, 1991; Möller et al., 2009; Pereira and D'Incao, 2012). The strong flow of freshwater in high rainfall years generates a physical barrier preventing the entrance of oceanic water and therefore the pink shrimp into the estuary (Möller et al., 2009; Pereira and D'Incao, 2012). The same pattern of greater post-larvae abundance related to the flow of ocean water into the adjacent coastal systems and the entry of post-larvae shrimp into the estuary can be observed for other penaeids, such as Farfantepenaeus subtilis (Pérez Farfante, 1967) and $F$. aztecus (Ives, 1891) (Lhomme, 1992; Cházaro-Olvera et al., 2009).

The greater abundance of post-larvae in SM, evidenced by PL2 model, may be due to the proximity of this inlet to the estuary connection with the ocean and also indicate the importance of shallow inlets in the lower estuary to the arrival and settlement of pink shrimp. In a similar way, post-larvae of Farfantepenaeus merguiensis (Longmuir, 1983) and Melicertus plebejus tend to seek shallow areas as soon as they enter in the estuary (Young and Carpenter, 1977; Adnan et al., 2002). The shallow inlets are recognized as important for the growth of pink shrimp because they can provide food and protection against predators (D’Incao, 1991). Moreover, it may suggest that the post-larvae in shallow inlets are protected against low tides that could carry them back to the ocean.

The models showed no significant difference in the abundance of juveniles between the inlets. That the lowest abundance of post-larvae was observed in the SA inlet may be evidence of migration of the pink shrimp during their growth phase in the estuary. This migration was mentioned by D'Incao (1991) as a consequence of the search for more favorable areas for feeding and protection. Almeida and D'Incao (1999) analyzed fishermen migrations to areas of greater production which shows indirectly the space and time variation on the shrimp abundance as presented by Ruas et al. (2011) for the artisanal fishery. The theory that the shrimp displays migration patterns on the estuary during the juvenile phase was difficult to prove and there are no studies that show this effect or in which stage of development (postlarvae or juvenile) this behavior occurs.

The movement of post-larvae to other estuarine areas was related by Vance et al. (1998) to $F$ merguiensis where they demonstrate that the increase of rain causes the decrease of salinity, therefore inhibiting the distribution of post-larvae to the inner regions of the estuary. The author also emphasizes that the variation on abundance is a result of a combination of hydrodynamic processes and behavioral changes associated with the development of the species. Staples (1980) observed that postlarvae of $F$. merguiensis move from the substrate to the water column and migrate up the estuary by the influence of tidal flooding with higher salinity. As no significant differences were found in the abundance of juvenile pink shrimp between inlets, it is therefore possible to suggest that this ontogenic behavior is also displayed by the juvenile, as the lowest abundance of post-larvae collected in SA may indicate that the pink shrimp reach this inlet already in the juvenile stage. 
Abundance of juveniles increased with salinity, and this was an expected result for the penaeid species in the Patos Lagoon estuary (D'Incao, 1991; Möller et al., 2009). The result observed in SM may be influenced by a greater abundance and survival of post-larvae in this inlet, whose growth rate was maintained and juvenile abundance increased after a period of time. According to the values recorded in this study, the SM salinity appears a more favorable condition for the survival of these organisms. According to Tsuzuki (1995), the post-larvae that populate the Patos Lagoon are very tolerant to salinity variance; however the author demonstrated that the lowest mortality rates occurred in salinities above 10 . D'Incao (1991) presented the preference of pink shrimp for a salinity of 10 in the Patos Lagoon estuary, and he also emphasizes that individuals can be found at salinities between 0 and 30. Costa et al. (2008), in an estuary of southeastern Brazil, showed the preference of penaeid juveniles for salinities above 15. This large tolerance can also be observed in our results since the effect of salinity on the abundance of juveniles in SA (interaction inlet $S A^{*}$ salt) showed that the highest abundances occurred in this inlet in lower salinities (10).

The results obtained in this study showed that there is no significant difference in the size of shrimps, showing that there was no segregation by size classes of juveniles between the inlets during the study. Possible differences could be found with a larger time period for data sampling: a longer growth period of the species in the estuary (D'Incao, 1984); the migrations of larger individuals to the ocean (D'Incao, 1990) and the pressure of the fishery when it is allowed from February onwards (Ruas et al., 2011).

\section{Blue crab: inlets and salinity influence}

The models showed differences in the abundance of the blue crab C. sapidus between inlets, and showed that there was preference for the SA inlet. As demonstrated in other estuaries and in laboratory experiments, habitat selection by this species appears as a life strategy during its development, and the blue crabs select the most favorable areas for feeding, growth, survival, protection from predators and avoidance of intraspecific competition and cannibalism (Orth and van Montfrans, 1987; Williams et al., 1990; Posey et al., 2005).

The effect of the interaction between the SA inlet and salinity on the abundance of the blue crab seems to indicate a possible explanation for the preference of these species for SA. The greatest abundance of crab in SA was found in lower salinities, showing that the water salinity may have an important role in these results. According to Posey et al., (2005), estuarine regions with low salinity can be considered a nursery ground for the blue crab due to the high abundance of small juveniles encountered in low salinities. When significant differences in carapace width (CW) were observed, it is possible to notice that the greatest abundance found in SA consisted of smaller individuals, and presumably younger than those found in SM. This is indicative of the use of SA as a nursery. The pursuit for areas with lower salinities can be associated with the growth of the species, and because these areas can provide protection against predators (Posey et al., 2005).

SA therefore proved to be an important area for juvenile $C$. sapidus. This result shows evidence of spatial segregation by size among individuals of the species in the estuary and that younger individuals may choose inlets that have favorable environmental conditions. The size segregation can occur in response to pressure and predation by competitive exclusion; smaller individuals were more vulnerable and occupy more protected areas (Willians et al., 1990; Posey et al., 2005). Segregation behavior to avoid competition for space and food was mentioned by Rodrigues and D'Incao (2014), when the authors demonstrated a migration of adult males to the upper estuary and of females towards the ocean.

\section{Submersed vegetation influence}

In this study, two models (PL1 and PL2) showed that significantly higher abundances of post-larvae of the pink shrimp occurred in the presence of vegetation. The model J 
did not show the presence of vegetation as a significant factor, but the $p$ value close to 0.05 indicates a tendency to find higher abundances in the prairie. These results show that there is a preference of the pink shrimp to settle on vegetated areas, as Garcia et al. (1996) had already demonstrated. However, the preference of post-larvae across the prairies is a new result for the species in question.

Haywood et al. (1995), even without identifying the mechanisms of settlement, highlights the importance of macrophyte as nurseries for post-larvae of Penaeus semisulcatus (De Haan, 1844) and P. esculentus (Haswell, 1879), and identifies for the latter species the preference for seagrass due to the type of food available. Nevertheless, there is no study that addresses the preference of post-larvae of $F$. paulensis in submerged vegetation. Despite this, a preference for seagrass habitats for settlement of megalopae of $C$. sapidus has been shown, where the attenuation of waves and currents across the prairies appears to be an important factor in habitat selection of megalopae. This is because it enables the active choice for seagrass meadows, allowing passive settlement (Orth andvan Montfrans, 1987; Lipcius et al., 2005). Thus, the post-larvae of the pink shrimp could also find the same benefits found by these species to the settlement on the prairies.

The seagrass prairies can be characterized as an important nursery for shrimp and crabs considering the high density of post-larvae and juveniles, as well as increased survival and the growth rate of the individuals in these habitats (Heck Jr et al., 2003). Inside the prairies, it is possible to find a greater quantity and quality of food, together with the fact that there is lower energy expenditure and less time escaping from predators due to a lower predation pressure (Perkins-Visser et al., 1996). However, the function of the protection offered by prairies to these animals in the Patos Lagoon estuary is questioned by Garcia $e t$ al. (1996). Low water transparency, a remarkable feature of the estuary, have a negative effect of predation on these crustaceans, and search for food may be the main factor explaining the greater abundance of decapods within the prairie (Garcia et al., 1996).

The pink shrimp is omnivorous and their diet includes plant fragments and detritus, and as they grow, the consumption shifts toward a predating behavior over benthic invertebrates (Albertoni et al., 2003; Soares et al., 2005; Jorgensen et al., 2009). Intake of plants, mostly by smaller individuals, may not directly represent a food resource but rather be associated with ingestion of small organisms attached to leaves of seagrass (Soares et al., 2008; Jorgensen et al., 2009). Therefore, the feeding habits and the search for food associated with prairies may justify the preference of juveniles for these habitats as suggested by Garcia et al. (1996). This feeding behavior may also explain the greatest abundance of post-larvae in vegetated funds.

The protection offered by vegetated areas in the estuary should also be considered as potentially influential in habitat selection by juveniles and smaller individuals, mainly by post-larvae, presumably because they are more vulnerable to predation. Studies with species of the genus Farfantepenaeus showed that there is a spatial segregation in the distribution of shrimp, and the greatest abundance of recruits $(\mathrm{CL}<8.0 \mathrm{~mm})$ and juveniles were associated with vegetated areas in the search for protection, while the sub adults did not show habitat selection behavior (Pérez-Castañeda and Defeo, 2001). In this study, no significant differences were found in the size of shrimps between vegetated and non-vegetated areas. However, the greater abundance of post-larvae in the prairie indicates a possible preference of smaller organisms by vegetated area, which suggests the protective function performed by vegetation.

In this work, the models did not show the vegetated bottoms as a significant factor for the abundance of the blue crab. This is the opposite of what has been presented for the species in other estuaries (Orth and van Montfrans, 1987; Williams et al., 1990) and in the Patos Lagoon (Garcia et al., 1996) that highlighted crabs' preference for this habitat. Nevertheless, when the differences 
found in CW of crabs between vegetated and unvegetated funds were analyzed, the submerged vegetation influenced the species, as the average size of individuals was lower in the prairie, indicating the preference of younger individuals by vegetation. The use of prairies and unvegetated areas for different size classes of blue crab can occur in response to predation pressure, where small individuals are found more frequently in dense prairies, while larger individuals are more often found in less dense prairies and unvegetated areas (Williams et al., 1990). In SM, where the highest averages of CW are found, no differences were found in the size of individuals between the vegetated and unvegetated bottom. It is possible to conjecture that larger crabs are able to explore areas that offer less protection.

According to the feeding behavior, the blue crab is considered generalist-opportunistic (Kapusta and Bemvenuti, 1998) and their diet in the estuary is mainly composed of detritus (plant and animal remains not yet digested) and the bivalve Erodona mactroides (Bosc, 1802) (Oliveira et al., 2006). Ontogenetic variation in feeding preference has already been observed, when the consumption of vegetation decreases as the individuals grow (Kapusta and Bemvenuti, 1998). Grasslands are safer habitats for younger animals against predation, providing protection for juveniles smaller than $25 \mathrm{~mm}$ of CW (Lipcius et al., 2005). Juveniles greater than this size are less susceptible to predation and are able to explore unvegetated areas in search of food (Lipcius et al., 2005). In contrast to the work of Garcia et al. (1996) it is suggested in this work that in addition to searching for food, the blue crab can find an environment that favors protection from predators in the prairies of submerged vegetation in the Patos Lagoon estuary. However, for best results it is suggested that future works take into account the variation of abundance as a function of carapace width of individuals.

The results of this study indicate that the pink shrimp $F$. paulensis and blue crab $C$. sapidus have an ontogenic habitat preference in the Patos Lagoon estuary and the salinity and the presence of submerged seagrass prairies influence the abundance and size of individuals. Although the results of this study confirm previous observations on the importance of prairies submerged vegetation to shrimps and blue crab, the preference of post-larvae and juveniles of the blue crab individuals across the prairie is a new result for the Patos Lagoon estuary. Thus, in addition to higher food supply in the prairies, they also search for protection as they are presumably more vulnerable to predation.

ACKNOWLEDGEMENTS - Authors are grateful to CAPES for the scholarship granted to the first author, and to the Laboratory of Decapod Crustaceans - Federal University of Rio Grande (FURG), where the study was conducted. Authors also gratefully acknowledge the contributions to English language revision of Emeline Pereira Gusmão and Eric Hoddy.

\section{REFERENCES}

Adnan, A.N.; Loneragan, N.R. and Connolly, R.M. 2002. Variability of and the influence of environmental factors on the recruitment of postlarval and juvenile Penaeus merguiensis in the Matang mangroves of Malaysia. Marine Biology, 141(2): 241-251.

Albertoni, E.F.; Palma-Silva, C. and Esteves, F.A. 2003. Natural diet of three species of shrimp in a tropical coastal lagoon. Brazilian Archives of Biology and Technology, 46(3): 395-403.

Almeida, H.L.P.S. and D'Incao, F. 1999. Análise do esforço de pesca do camarão-rosa (Farfantepenaeus paulensis) na Lagoa dos Patos, Brasil. Atlântica, 21: 77-92.

Bulger, A.J.; Lowery, T.A. and Monaco, M.E. 1995. Estuarine-catadromy: a life history strategy coupling marine and estuarine environments via coastal inlets. ELMR Rep. No. 14. NOAA/NOS Strategic Environmental Assessments Division, Silver Spring, EUA, 110 p.

Burnham, P.K. and Anderson, D.R. 2002. Models Selection and Multi-Model Inference: a practical information - theoretic approach. Springer-Verlag, New York. 488p.

Calazans, D. 1993. Key to the larvae and decapodids of genera of the infraorder Penaeidea from the southern Brazilian coast. Nauplius, 1: 45-62.

Cházaro-Olvera, S.; Winfield, I. and Coria-Olvera, V. 2009. Transport of Farfantepenaeus aztecus postlarvae in three lagoon-system inlets in the southwestern Gulf of Mexico. Crustaceana, 82(4): 425-437.

Copertino, M. and Seeliger, U. 2010. Habitats de Ruppia maritima e de macroalgas. In: U. Seeliger and C. Odebrecht (eds), O estuário da Lagoa dos Patos: um século de transformaçóes. FURG, Rio Grande, Brasil, 179p. 
Costa, R.C.; Lopes, M.; Castilho, A.L.; Fransozo, A. and Simóes, S.M. 2008. Abundance and distribution of juvenile pink shrimps Farfantepenaeus spp. in a mangrove estuary and adjacent bay on the northern shore of São Paulo State, southeastern Brazil. Invertebrate Reproduction and Development, 52: 5158.

D’Incao, F. 1984. Estudo sobre o crescimento de Penaeus (Farfantepenaeus) paulensis Pérez-Farfante, 1967, da Lagoa dos Patos, RS, Brasil (Decapoda, Penaeidae). Atlântica, 7: 73-84.

D'Incao, F. 1990. Mortalidade de Penaeus (Farfantepenaues) paulensis Pérez Farfante, 1967 no estuário da Lagoa dos Patos, Rio Grande do Sul, Brasil (Crustacea, Penaeidae). Atlântica, 12(2): 3151

D’Incao, F. 1991. Pesca e biologia da Penaeus paulensis na Lagoa dos Patos, RS. Atlântica, 13(1): 159-169.

D'Incao, F. 1999. Subordem Dendrobranchiata. In: L. Buckup and G. Bond-Buckup, (eds), Os Crustáceos do Rio Grande do Sul. UFRGS, Porto Alegre, Brasil, 503p.

D'Incao, F; Valentini, H. and Rodrigues, L.F. 2002. Avaliação da pesca de camaróes nas regióes sudeste e sul do Brasil. Atlântica, 24(2): 103-116.

Epifanio, C.E. 2007. Biology of larvae. In: V.S. Kennedy and L.E. Cronin (eds), The blue crab Callinectes sapidus. Maryland Sea Grant College, Maryland, USA, 774p.

Garcia, A.M.; Vieira, J.P.; Bemvenuti, C.E. and Geraldi, R.M. 1996. Abundância e diversidade da assembléia de crustáceos decápodos dentro e fora de uma pradaria de Ruppia maritima no estuário da Lagoa dos Patos (RS-Brasil). Nauplius, 4(1):113-128.

Haywood, M.D.E.; Vance, D.J. and Loneragan, N.R. 1995. Seagrass and algal beds as nursery habitats for tiger prawns (Penaeus semisulcatus and P. esculentus) in a tropical Australian estuary. Marine Biology, 122: 213-223.

Heck Jr., K.L.; Hays, G. and Orth, R.J. 2003. Critical evaluation of the nursery role hypothesis for seagrass meadows. Marine Ecology Progress Series, 253: 123136.

Hines, A.H.; Lipcius, R.N. and Haddon, A.M. 1987. Population dynamics and habitat partitioning by size, sex, and molt stage of blue crabs Callinectes sapidus in a subestuary of central Chesapeake Bay. Marine Ecology Progress Series, 36: 55-64.

Hovel, A.K. and Lipcius, R.N. 2002. Effects of seagrass habitat fragmentation on juvenile blue crab survival and abundance. Journal of Experimental Marine Biology and Ecology, 271: 75-98.

Jorgensen, P.; Bemvenuti, C.E. and Hereu, C.M. 2009. Feeding of Farfantepenaeus paulensis (Pérez-Farfante, 1967) (Crustacea: Penaeidae) inside and outside experimental pen-culture in southern Brazil. PanAmerican Journal of Aquatic Sciences, 4(1): 39-51.

Kalikoski, D.C. and Vasconcellos, M. 2013. Estudo das condiçóes técnicas, econômicas e ambientais da pesca de pequena escala no estuário da Lagoa dos Patos, Brasil: uma metodologia de avaliaçáo. FAO, Circular de Pesca e Aquicultura No. 1075, Roma, 200p.

Kapusta, S.C. and Bemvenuti, C.E. 1998. Atividade nictimeral de alimentação de juvenis de Callinectes sapidus, Rathbun, 1895 (Decapoda: Portunidae) numa pradaria de Ruppia maritima L. e num plano náo vegetado, numa enseada estuarina da Lagoa dos
Patos, RS, Brasil. Nauplius, 6(1):41-52.

Lee, K.S.; Park, S.R. and Kim, Y.K. 2007. Effects of irradiance, temperature, and nutrients on growth dynamics of seagrasses: A review. Journal of Experimental Biology and Ecology, 350: 144-175.

Lhomme, F. 1992. Recruitment of postlarvae of the shrimp Penaeus subtilis (Perez Farfante, 1967) in 2 estuaries of French-Guiana. Annales de I'Institut Océanographique, 68(1-2): 169-178.

Lipcius, R.N.; Seitz, R.D.; Seebo, M.S. and ColónCarrión, D. 2005. Density, abundance and survival of the blue crab in seagrass and unstructured salt marsh nurseries of Chesapeake Bay. Journal of Experimental Marine Biology and Ecology, 319: 6980 .

McCullagh, P. and Nelder, J.A. 1989. Generalized Linear Models. Chapman and Hall, New York, $511 \mathrm{p}$.

Melo, G.A.S. 1996. Manual de Identificação dos Brachyura (Caranguejos e Siris) do Litoral Brasileiro. Plêiade, São Paulo, 603p.

Möller, O.O.; Castelo, J.P. and Vaz, N.A. 2009. The effect of river discharge and winds on the interannual variability of the Pink shrimp Farfantepenaeus paulensis production in Patos Lagoon. Estuaries and Coasts, 32(4): 787-796.

Oliveira, A.; Pinto, K.T.; Santos, D.P.D. and D'Incao, F. 2006. Dieta natural do siri-azul Callinectes sapidus (Decapoda, Portunidae) na região estuarina da Lagoa dos Patos, Rio Grande, Rio Grande do Sul, Brasil. Iheringia, Série Zoologia, 96(3): 305-313.

Orth, R.J. and van Montfrans, J. 1987. Utilization of a seagrass meadow and tidal marsh creek by blue crabs Callinectes sapidus. I. Seasonal and annual variations in abundance with emphasis on post-settlement juveniles. Marine Ecology Progress Series, 41: 283294.

Pereira, N. and D'Incao, F. 2012. Relationship between rainfall, pink shrimp harvest (Farfantepenaeus paulensis) and adult stock, associated with El Niño and La Niña phenomena in Patos Lagoon, southern Brazil. Journal of the Marine Biological Association of the United Kingdom, 92(7): 1451-1456.

Pérez-Castañeda, R. and Defeo, O. 2001. Population variability of four sympatric Penaeid shrimps (Farfantepenaeus spp.) in a Tropical Coastal Lagoon of Mexico. Estuarine, Coastal and Shelf Science, 52: 631-641.

Pérez-Castañeda, R. and Defeo, O. 2004. Spatial distribution and structure along ecological gradients: penaeid shrimps in a tropical estuarine habitat of Mexico. Marine Ecology Progress Series, 273: 173185.

Pérez-Castañeda, R.; Blanco-Martínez, Z.; SánchezMartinez, J.G.; Rábago-Castro, J.L.; AguirreGuzmán, G. and Vásquez-Sauceda, M.L. 2010. Distribution of Farfantepenaeus aztecus and $F$. duorarum on submerged aquatic vegetation habitats along a subtropical coastal lagoon (Laguna Madre, Mexico). Journal of the Marine Biological Association of United Kingdom, 90(3): 445-452.

Perkins-Visser, E.; Wolcotth, T.G. and Wolcotth, D.L. 1996. Nursery role of seagrass beds: enhanced growth of juvenile blue crabs (Callinectes sapidus Rathbun). Journal of Experimental Marine Biology and Ecology, 198: 155-173.

Posey, M.H.; Alphin, T.D.; Harwell, H. and Allen, B. 2005. Importance of low salinity areas for juvenile blue crabs, Callinectes sapidus Rathbun, in river- 
dominated estuaries of southeastern United States. Journal of Experimental Marine Biology and Ecology, 319: 81-100.

Quinn, G.P. and Keough, M.J. 2002. Experimental Design and Data Analysis for Biologists. Cambridge, New York, 537p.

R Development Core Team. 2013. R: a language and environment for statistical computing. R Foundation for Statistical Computing. Available at: http://www.R-project.org.

Renfro, W.C. 1963. Small beam net for sampling postlarval shrimp. Circular United States Department of Fisheries and Wildlife Service, 161: 86-87.

Rodrigues, M.A. and D'Incao, F. 2008. Comparação do crescimento entre Callinectes sapidus (Crustacea, Decapoda, Portunidae) coletados em campo e mantidos em condiçôes controladas. Iheringia, Série Zoologia, 98(3): 372-378.

Rodrigues, M.A. and D'Incao, F. 2014. Biologia reprodutiva do siri-azul Callinectes sapidus no estuário da Lagoa dos Patos, RS, Brasil. Boletim do Instituto de Pesca, 40(2): 223-236.

Ruas, V.M.; Dumont, L.F. and D'Incao, F. 2011. Avaliaçáo do tamanho de captura e estimativa da abundância do camarão-rosa Farfantepenaeus paulensis (Pérez Farfante 1967) no entorno da Ilha dos Marinheiros, estuário da Lagoa dos Patos, RS, Brasil. Atlântica, 33(2): 161-172.

Sánchez, A.J. 1997. Habitat preference of Penaeus duorarum Burkenroad (Crustacea: Decapoda) in a tropical coastal lagoon, southwest Gulf of Mexico. Journal of Experimental Marine Biology and Ecology, 217: 107-117.

Shaw, R.G. and Mitchell-Olds, T. 1993. Anova for unbalanced data: an overview. Ecology, 74(6): 16381645.

Soares, R.; Peixoto, S.; Wasielesky, W. and D'Incao, F. 2005. Feeding rhythms and diet of Farfantepenaeus paulensis under pen culture in Patos Lagoon estuary, Brazil. Journal of Experimental Marine Biology and Ecology, 322: 167-176.

Soares, R.; Peixoto, S.; Wasielesky, W. and D'Incao, F. 2008. Effects of feeding plant material on growth and survival of pink shrimp Farfantepenaeus paulensis. Atlântica, 30(1): 17-22.

Staples, D.J. 1980. Ecology of juvenile and adolescent banana prawns, Penaeus merguiensis, in a mangrove estuary and adjacent off-shore area of the Gulf of Carpentaria. I. immigration and settlement of postlarvae. Australian Journal of Marine and Freshwater Research, 31(5): 635-652.

Tsuzuki, M. Y. 1995. Efeitos da temperatura e da salinidade na sobrevivência e crescimento de pós-larvas do camarão-rosa Penaeus paulensis (Pérez-Farfante, 1967) (Decapoda - Penaeidae). Universidade Federal do Rio Grande, Rio Grande, Brazil, Master Dissertation, 125p. [Unpublished].

Underwood, A.J. 1981. Techniques of analysis of variance in experimental marine biology and ecology. Oceanography and Marine Biology An Annual Review, 19: 513-605.

Vance, D.J.; Haywood, M.D.E.; Heales, D.S.; Kenyon, R.A. and Loneragan, N.R. 1998. Seasonal and annual variation in abundance of postlarval and juvenile banana prawns Penaeus merguiensis and environmental variation in two estuaries in tropical northeastern Australia: a six year study. Marine Ecology Progress Series, 163: 21-36.
Vieira, R.R.R. and Calazans, D.K. 2010. Chave ilustrada para identificaçáo das zoés de Brachyura do estuário da Lagoa dos Patos (RS) e região costeira adjacente. Biota Neotropica, 10(3): 431-437.

Williams, A.H.; Coen, L.D. and Stoelting M.S. 1990. Seasonal abundance, distribution, and habitat selection of juvenile Callinectes sapidus (Rathbun) in the northern Gulf of Mexico. Journal of Experimental Marine Biology and Ecology, 137: 165-183.

Young, P.C. and Carpenter, S.M. 1977. Recruitment of postlaval Penaeid prawns to nursery areas in Moreton Bay, Queensland Australian Journal Marine Freshwater Research, 28: 745-773.

Zar, J.H. 1984. Biostatistical Analysis. Prentice-Hall, New Jersey. 718p
Submitted 13 May 2014 Accepted 11 October 2014 